\title{
Antibacterial activity of essential oils from Citrus hystrix (makrut lime) against respiratory tract pathogens
}

\author{
Vimol Srisukh $^{\mathrm{a}}$, Chanwit Tribuddharat ${ }^{\mathrm{b}}$, Veena Nukoolkarn ${ }^{\mathrm{c}}$, Nuntavan Bunyapraphatsara ${ }^{\mathrm{c}}$, \\ Kulkanya Chokephaibulkit $^{\mathrm{d}}$, Siwimol Phoomniyom ${ }^{\mathrm{b}}$, Sirirat Chuanphung ${ }^{\mathrm{b}}$, Somporn Srifuengfung ${ }^{\mathrm{b}, *}$ \\ a Department of Food Chemistry, Faculty of Pharmacy, Mahidol University, Phayathai Road, \\ Bangkok 10400 Thailand \\ b Department of Microbiology, Faculty of Medicine Siriraj Hospital, Mahidol University, Prannok Road, \\ Bangkok 10700 Thailand \\ c Department of Pharmacognosy, Faculty of Pharmacy, Mahidol University, Phayathai Road, \\ Bangkok 10400 Thailand \\ d Department of Pediatrics, Faculty of Medicine Siriraj Hospital, Mahidol University, Prannok Road, \\ Bangkok 10700 Thailand
}

*Corresponding author, e-mail: sissf@mahidol.ac.th

Received 24 Nov 2011

Accepted 27 Apr 2012

\begin{abstract}
Many essential oils have antibacterial activity with a potential use in medicine. Citrus hystrix DC, or makrut lime, contains two essential oils, makrut leaf oil and makrut (fruit peel) oil, of which we determined the inhibitory effect against respiratory pathogens and evaluated their active components. Gas chromatography-mass spectrometry was used to analyse the chemical composition of the essential oils. The antibacterial activities were tested by disc-diffusion and broth microdilution methods against 411 isolates of groups A, B, C, F, G streptococci, Streptococcus pneumoniae, Haemophilus influenzae, Staphylococcus aureus (methicillin-resistant and -sensitive S. aureus) and Acinetobacter baumannii, obtained from patients with respiratory tract infections. Makrut leaf oil and makrut oil were both effective against all the pathogens with minimal inhibitory concentration (MIC) ranges of $0.06-68 \mathrm{mg} / \mathrm{ml}$ and $0.03-17.40 \mathrm{mg} / \mathrm{ml}$, respectively. Citronellal was found to be the major component $(80.04 \%)$ in makrut leaf oil and had the lowest MIC. In contrast, makrut oil consisted of several components (limonene 40.65\%, terpinene-4-ol 13.71\%, $\alpha$-terpineol 13.20\%), and the most active component was $\alpha$-terpineol, followed by terpinene-4-ol, and limonene. These results suggest that makrut leaf oil, makrut oil, and their components (citronellal, $\alpha$-terpineol, terpinene-4-ol) may be alternative natural source medicine to prevent and treat many bacterial diseases.
\end{abstract}

KEYWORDS: kaffir lime, $\alpha$-terpineol

\section{INTRODUCTION}

Respiratory tract infection is a public health concern in global scale. Controlling the number and growth of pathogens by effective natural products have been the prime targets of research. Essential oils and extracts from a wide variety of plants have long been used for medicinal purposes. They are potential sources of novel drugs especially against bacterial pathogens ${ }^{1-3}$. Citrus hystrix DC, commonly known as makrut lime, is a common tropical herb in the family Rutaceae found everywhere in Southeast Asia ${ }^{4}$. Makrut lime is a thorny bush with aromatic leaves and dark green fruits with irregular bumpy surface (Fig. 1). The valued parts of makrut lime are the leaves and fruit peel. Makrut lime is a key ingredient in many Thai, Cambodian, Indonesian, Laotian, Malaysian, and Philippine cuisines. There are two essential oils that can be extracted from makrut lime, the makrut lime leaf oil and makrut lime fruit peel oil (in short, makrut oil). The essential oils have been used as flavour and fragrance agents, as well as in perfumery and medicinal preparation ${ }^{4}$.

Essential oils extracted from plants may have antibacterial properties ${ }^{5}$ with synergistic interactions among them ${ }^{6}$. Essential oils usually consist of a large number of components and it is likely that their mode of action involves many targets in bacterial cells. A number of essential oil components have been identified as antibacterials such as carvacrol ${ }^{6-8}$, $\operatorname{citral}^{7}$, eugenol ${ }^{6,7}$, geraniol ${ }^{7}$, perillaldehyde ${ }^{6,7}$, and thymol $^{8}$. In addition, essential oils have antioxidant ${ }^{2}$, repellent, insecticidal ${ }^{9}$, antifungal ${ }^{10}$, antiviral ${ }^{11}$, and antiparasitic activities ${ }^{12}$. Makrut lime oil was reported 


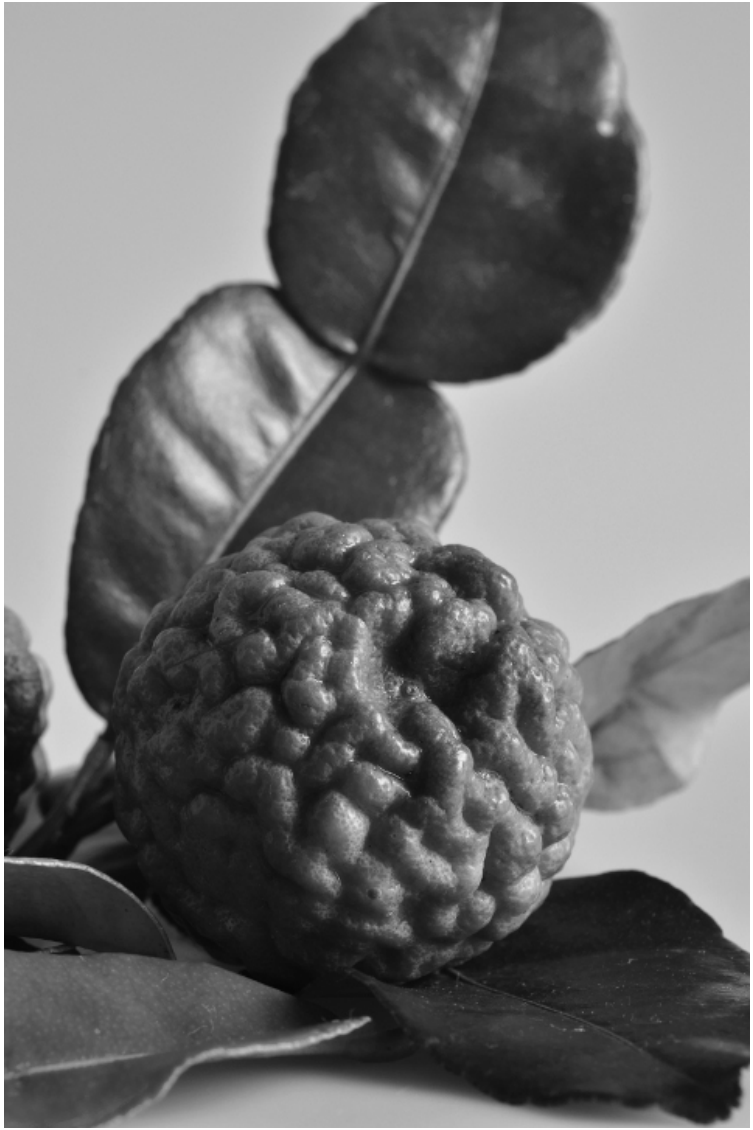

Fig. 1 Fruits and leaves of makrut lime (Citrus hystrix).

to be effective against 20 serotypes of Salmonella and 5 species of other enterobacteria ${ }^{13}$. This study aimed to evaluate the inhibitory effect of makrut lime essential oils against bacterial respiratory pathogens and to determine the active components responsible for the inhibitory activity.

\section{MATERIALS AND METHODS}

The makrut leaf oil (batch no. 5209234-1/1009; density $=0.86 \mathrm{~g} / \mathrm{ml}$ ) and makrut oil (batch no. $5209234 / 1009$; density $=0.87 \mathrm{~g} / \mathrm{ml}$ ), were obtained from Thai-China Flavours and Fragrances Co., Ltd. The products were prepared by steam distillation. The components of the essential oils were analysed by gas chromatography-mass spectrometry (GC-MS). Samples of makrut leaf oil and makrut oil were diluted to $100 \mathrm{ppm}$ prior to the analysis. The diluted oils were then analysed by GC-MS ${ }^{14}$, using a HewlettPackard HP 6890 Series GC System and HewlettPackard HP 5973 Mass selective detector. Samples were injected on a capillary column (HP-INNOWAX; $60 \mathrm{~m} \times 0.25 \mathrm{~mm} \times 0.25 \mu \mathrm{m}$ ) well coated with cross linked PEG. The carrier gas was Helium (99.99\%), at the flow rate of $0.80 \mathrm{ml} / \mathrm{min}$. The inlet injection temperature was $200^{\circ} \mathrm{C}$ with the inlet split ratio of 5:1. The GC oven temperature was kept at $70^{\circ} \mathrm{C}$ for $2 \mathrm{~min}$ and programmed to $220^{\circ} \mathrm{C}$ at a rate of $4{ }^{\circ} \mathrm{C} / \mathrm{min}$, held for $5 \mathrm{~min}$ and finally at $10^{\circ} \mathrm{C} / \mathrm{min}$ and programmed to $300^{\circ} \mathrm{C}$, held for $3 \mathrm{~min}$. The $\mathrm{GC} / \mathrm{MS}$ interface (Auxs) temperature was set at $250{ }^{\circ} \mathrm{C}$. The Mass Spectrometer condition was as follows: EL Source temperature $250^{\circ} \mathrm{C}$, Emission 34.6, Ele energy $70 \mathrm{eV}$, Qoadrole temperature $150^{\circ} \mathrm{C}$, Scan mode: 303450; EM Volt 1450 . The MS library was Wiley $275 /$ version 6.0 , NBS $45 \mathrm{~K}$. The pure compounds in analytical grade of citronellal (density $=0.86 \mathrm{~g} / \mathrm{ml}$ ), limonene $($ density $=0.84 \mathrm{~g} / \mathrm{ml})$, terpinene-4-ol (density $=$ $0.93 \mathrm{~g} / \mathrm{ml}$ ),$\alpha$-terpineol (density $=0.94 \mathrm{~g} / \mathrm{ml}$ ) used in the testings were purchased from Sigma Chemical Co., USA.

A total of 411 clinical isolates used in the inhibitory testing were Acinetobacter baumannii (50 isolates), Groups A (61 isolates), B (27 isolates), C (4 isolates), F (3 isolates), G streptococci (11 isolates), Haemophilus influenzae (52 isolates), Moraxella catarrhalis (52 isolates), methicillin-resistant Staphylococcus aureus (MRSA; 50 isolates), methicillinsensitive $S$. aureus (MSSA; 50 isolates) and Streptococcus pneumoniae (51 isolates). These isolates were from respiratory tract specimens (throat swab, pus in tonsils and adenoid tissues, sputum, bronchial wash, bronchoalveolar lavage) or blood collected from patients who had respiratory symptoms at Siriraj Hospital, a tertiary care centre in Bangkok, during January 2008-December 2010. Sputum was considered acceptable for culture if it contained more than 25 polymorphonuclear cells and less than 25 epithelial cells per low-powered field. Bacterial identification, disc-diffusion, and broth microdilution methods were performed by standard microbiological techniques ${ }^{15,16}$. Identification of the Lancefield groups of $\beta$-haemolytic streptococci was done by using a rapid latex agglutination test kit, Remel streptex (Remel Co., USA) according to the manufacturer's guideline.

The antibacterial activity of the essential oils was tested by disc-diffusion and broth microdilution methods. In the disc-diffusion method, a sterile Whatman disc $(6 \mathrm{~mm})$ saturated with $10 \mu \mathrm{l}$ of essential oil ${ }^{17}$ was put on a lawn of a bacterial inoculum which has a turbidity in $1 \%(\mathrm{w} / \mathrm{v})$ tryptone water equated to a McFarland No 0.5 standard (approximately $10^{8} \mathrm{CFU} / \mathrm{ml}$ ). All values of inhibition zones were expressed as mean \pm standard deviation. S. pneumoniae ATCC 49619, H. influenzae ATCC 49247, and S. aureus ATCC 25923 were used as quality controls. For broth 
Table 1 Minimal inhibitory concentrations (MIC) and Minimal bactericidal concentrations (MBC).

\begin{tabular}{|c|c|c|c|c|c|c|c|c|}
\hline \multirow[t]{2}{*}{ Pathogens } & \multicolumn{4}{|c|}{ Makrut lime leaf oil (mg/ml) } & \multicolumn{4}{|c|}{ Makrut lime oil (mg/ml) } \\
\hline & MIC range & $\mathrm{MIC}_{50}$ & $\mathrm{MIC}_{90}$ & $\mathrm{MBC}$ range & MIC range & $\mathrm{MIC}_{50}$ & $\mathrm{MIC}_{90}$ & $\mathrm{MBC}$ range \\
\hline A. baumannii & $2.10-17$ & 4.30 & 8.50 & $4.30-68$ & $1.10-4.40$ & 1.10 & 4.40 & $1.10-8.70$ \\
\hline Group A strep & $0.30-8.50$ & 1.10 & 4.30 & $0.30-8.50$ & $0.30-4.40$ & 2.20 & 2.20 & $0.30-4.40$ \\
\hline Group B strep & $0.30-8.50$ & 0.50 & 1.10 & $0.30-8.50$ & $0.30-8.70$ & 1.10 & 2.20 & $0.30-17.40$ \\
\hline Group C strep & $0.30-4.30$ & 0.50 & 4.30 & $0.30-4.30$ & $0.30-4.40$ & 0.50 & 4.40 & $0.30-4.40$ \\
\hline Group F strep & $0.30-4.30$ & 2.10 & 4.30 & $0.30-4.30$ & $0.50-4.40$ & 1.10 & 4.40 & $0.50-4.40$ \\
\hline Group G strep & $0.30-4.30$ & 0.30 & 2.10 & $0.30-4.30$ & $0.30-4.40$ & 1.10 & 4.40 & $0.50-4.40$ \\
\hline H. influenzae & $0.06-0.50$ & 0.30 & 0.30 & $0.06-1.10$ & $0.06-0.50$ & 0.10 & 0.30 & $0.06-1.10$ \\
\hline M. catarrhalis & $0.03-0.25$ & 0.03 & 0.03 & $0.03-0.50$ & $0.03-0.25$ & 0.03 & 0.03 & $0.03-0.50$ \\
\hline MSSA & $1.10-34$ & 8.50 & 17 & $8.50-68$ & $1.10-8.70$ & 2.20 & 4.40 & $1.10-8.70$ \\
\hline MRSA & $2.10-68$ & 8.50 & 34 & $8.50-68$ & $1.1-17.40$ & 2.20 & 4.40 & $2.20-17.40$ \\
\hline S. pneumoniae & $0.30-4.30$ & 0.50 & 2.10 & $0.30-8.50$ & $0.30-4.40$ & 0.50 & 1.10 & $0.30-4.40$ \\
\hline
\end{tabular}

$\mathrm{MIC}_{50}$ and $\mathrm{MIC}_{90}$ are the minimal inhibitory concentrations required to inhibit the growth of $50 \%$ and $90 \%$ of bacteria, respectively.

microdilution method, the broth was supplemented with $0.25 \%$ (v/v) tween-20 (Sigma Chemical Co., USA). Two-fold serial dilutions of essential oils were prepared in a microtitre plate. The minimal inhibitory concentration (MIC) was lowest concentration of essential oil inhibiting visible bacterial growth after incubation for $20-24 \mathrm{~h}$ at $35^{\circ} \mathrm{C}$. Cell suspensions (1 loop) from the wells showing no growth were subcultured on sheep blood agar (or chocolate agar in case of $H$. influenzae) to determine if the inhibition was reversible or permanent. Minimal bactericidal concentration (MBC) was determined as the highest dilution (i.e., lowest concentration) at which no growth occurred on the agar plates.

\section{RESULTS}

The results of gas chromatography analysis found that the most predominate component in makrut leaf oil was citronellal $(80.04 \%)$ whereas in makrut oil were limonene $(40.65 \%)$, terpinene-4-ol (13.71\%) and $\alpha$-terpineol (13.20\%). Other components were presence in trace.

Both makrut leaf oil and makrut oil exhibited antibacterial properties for all bacteria tested by the discdiffusion method, especially against $M$. catarrhalis (Fig. 2). The MIC and MBC of makrut leaf oil and makrut oil were lowest against $M$. catarrhalis and $H$. influenzae (indicating best activity), followed by S. pneumoniae, Streptococcus spp., A. baumannii, MSSA, and MRSA, respectively (Table 1). Taken together, the MIC of makrut leaf oil was in the range of $0.06-68 \mathrm{mg} / \mathrm{ml}$ and that for makrut oil was $0.03-$ $17.40 \mathrm{mg} / \mathrm{ml}$. Although the MIC and MBC varied among tested bacteria, the MIC in most cases was

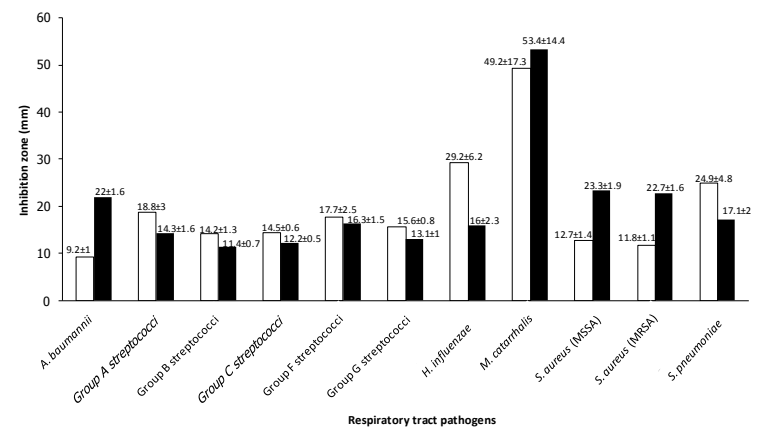

Fig. 2 Inhibition zones of makrut lime leaf oil ( $\square$ ) and makrut lime oil ( $\square$ ) by disc-diffusion method. Values were means \pm standard deviation.

equivalent to $\mathrm{MBC}$ indicating a bactericidal action of oil.

In the active component testing citronellal, the major component in makrut leaf oil, was found to be more active than the whole makrut leaf oil against A. baumannii, Streptococcus spp., MSSA, and MRSA (Table 2). Likewise, $\alpha$-terpineol, followed by terpinene-4-ol, were more active against $A$. baumannii, Streptococcus spp., and $H$. influenzae ATCC 49766 than makrut lime oil (Table 3). However, limonene, the most predominate component of makrut oil, had a much less antibacterial activity.

The antibacterial activity of makrut leaf oil and makrut lime oil was found to be stable upon storage at room temperature up to 4 months. The MIC and MBC values at 4 months were not different from those at 1 , 2 , and 3 months of storage. 
Table 2 Effect of citronellal in makrut lime leaf oil on pathogens.

\begin{tabular}{|c|c|c|c|c|c|c|}
\hline \multirow[t]{2}{*}{ Pathogens } & \multicolumn{3}{|c|}{ Makrut lime leaf oil } & \multicolumn{3}{|c|}{ Major component Citronellal } \\
\hline & $\begin{array}{l}\text { Inhibition zone } \\
(\mathrm{mm})\end{array}$ & $\begin{array}{c}\mathrm{MIC} \\
(\mathrm{mg} / \mathrm{ml})\end{array}$ & $\begin{array}{c}\mathrm{MBC} \\
(\mathrm{mg} / \mathrm{ml})\end{array}$ & $\begin{array}{l}\text { Inhibition zone } \\
(\mathrm{mm})\end{array}$ & $\begin{array}{c}\mathrm{MIC} \\
(\mathrm{mg} / \mathrm{ml})\end{array}$ & $\begin{array}{c}\mathrm{MBC} \\
(\mathrm{mg} / \mathrm{ml})\end{array}$ \\
\hline A. baumannii & 10 & 8.5 & 8.5 & 13 & 1.1 & 4.3 \\
\hline Group A streptococci & 16 & 4.3 & 4.3 & 15 & 0.5 & 1.1 \\
\hline Group B streptococci & 11 & 4.3 & 4.3 & 10 & 1.1 & 1.1 \\
\hline Group C streptococci & 15 & 4.3 & 4.3 & 15 & 0.3 & 0.3 \\
\hline Group F streptococci & 17 & 2.1 & 8.5 & 17 & 1.1 & 1.1 \\
\hline Group G streptococci & 16 & 4.3 & 4.3 & 15 & 1.1 & 1.1 \\
\hline H. influenzae & 21 & 0.3 & 0.3 & 20 & 0.5 & 0.5 \\
\hline H. influenzae ATCC 49766 & 22 & 0.5 & 0.5 & 20 & 0.3 & 0.5 \\
\hline S. aureus ATCC 25923 & 19 & 1.1 & 1.1 & 22 & 1.1 & 1.1 \\
\hline S. aureus (MSSA) & 14 & 4.3 & 34 & 14 & 1.1 & 8.6 \\
\hline S. aureus (MRSA) & 15 & 8.5 & 34 & 15 & 1.1 & 8.6 \\
\hline S. pneumoniae & 24 & 0.3 & 0.3 & 24 & 0.5 & 0.5 \\
\hline S. pneumoniae ATCC 49619 & 23 & 0.5 & 0.5 & 23 & 0.5 & 0.5 \\
\hline
\end{tabular}

$\mathrm{MIC}=$ Minimal inhibitory concentration; $\mathrm{MBC}=$ Minimal bactericidal concentration.

Table 3 Effect of limonene, terpinen-4-ol, and $\alpha$-terpineol in makrut lime oil on pathogens.

\begin{tabular}{|c|c|c|c|c|c|c|c|c|c|c|}
\hline \multirow[t]{3}{*}{ Pathogens } & \multirow{2}{*}{\multicolumn{3}{|c|}{ Makrut lime oil }} & \multicolumn{7}{|c|}{ Various components } \\
\hline & & & & \multicolumn{3}{|c|}{ Limonene } & \multicolumn{2}{|c|}{ Terpinene-4-ol } & \multicolumn{2}{|c|}{$\alpha$-terpineol } \\
\hline & $\begin{array}{l}\text { Inh. } \\
\text { zone } \\
(\mathrm{mm})\end{array}$ & $\begin{array}{c}\mathrm{MIC} \\
(\mathrm{mg} / \mathrm{ml})\end{array}$ & $\begin{array}{c}\mathrm{MBC} \\
(\mathrm{mg} / \mathrm{ml})\end{array}$ & $\begin{array}{l}\text { Inh. } \\
\text { zone } \\
(\mathrm{mm})\end{array}$ & $\begin{array}{c}\mathrm{MIC} \\
(\mathrm{mg} / \mathrm{ml})\end{array}$ & $\begin{array}{c}\mathrm{MBC} \\
(\mathrm{mg} / \mathrm{ml})\end{array}$ & $\begin{array}{c}\mathrm{MIC} \\
(\mathrm{mg} / \mathrm{ml})\end{array}$ & $\begin{array}{c}\mathrm{MBC} \\
(\mathrm{mg} / \mathrm{ml})\end{array}$ & $\begin{array}{c}\mathrm{MIC} \\
(\mathrm{mg} / \mathrm{ml})\end{array}$ & $\begin{array}{c}\mathrm{MBC} \\
(\mathrm{mg} / \mathrm{ml})\end{array}$ \\
\hline A. baumannii & 22 & 1.10 & 1.10 & 6 & $>134$ & $>134$ & 5 & 5 & 0.07 & 0.10 \\
\hline Group A streptococci & 14 & 2.20 & 2.20 & 6 & $>134$ & $>134$ & 1.25 & 2.50 & 0.60 & 0.60 \\
\hline Group B streptococci & 11 & 4.40 & 4.40 & 7 & $>134$ & $>134$ & 0.30 & 0.60 & 0.60 & 0.60 \\
\hline Group C streptococci & 12 & 4.40 & 4.40 & 6 & $>134$ & $>134$ & 0.15 & 0.15 & 0.60 & 0.60 \\
\hline Group F streptococci & 15 & 1.10 & 1.10 & 6 & $>134$ & $>134$ & 1.25 & 2.50 & 1.20 & 1.20 \\
\hline Group G streptococci & 13 & 4.40 & 4.40 & 6 & $>134$ & $>134$ & 0.15 & 0.30 & 1.20 & 1.20 \\
\hline H. influenzae & 17 & 0.30 & 0.30 & 12 & 67 & 67 & 0.15 & 0.30 & 0.70 & 0.70 \\
\hline H. influenzae АТCC 49766 & 17 & 0.10 & 0.10 & 12 & 67 & 67 & 5 & 5 & 0.07 & 0.07 \\
\hline S. aureus ATCC 25923 & 26 & 1.10 & 1.10 & 11 & $>134$ & $>134$ & 10 & 20 & 0.30 & 1.20 \\
\hline S. aureus (MRSA) & 20 & 2.20 & 2.20 & 6 & $>134$ & $>134$ & 2.50 & 5 & 2.40 & 2.40 \\
\hline S. aureus (MSSA) & 21 & 4.40 & 4.40 & 6 & $>134$ & $>134$ & 10 & 20 & 2.40 & 2.40 \\
\hline S. pneumoniae & 20 & 0.30 & 0.30 & 11 & 33 & 67 & 0.15 & 0.15 & 0.30 & 0.30 \\
\hline S. pneumoniae ATCC 49619 & 16 & 0.50 & 0.50 & 8 & 67 & $>134$ & 2.50 & 2.50 & 0.60 & 0.60 \\
\hline
\end{tabular}

$\mathrm{MIC}=$ Minimal inhibitory concentration; $\mathrm{MBC}=$ Minimal bactericidal concentration.

\section{DISCUSSION}

Our study revealed the antibacterial effect of makrut leaf oil and makrut oil against respiratory bacterial pathogens. A preliminary study of antibacterial activities on medicinal herbs of Thai food ingredients against food-borne pathogens such as Bacillus cereus, S. aureus, and Salmonella Typhi was reported ${ }^{18}$. Our results are in agreement with a previous study that found makrut oil and ethanol extract of makrut fruit peels had a greater antibacterial effect than the extracts of makrut leaves ${ }^{13}$. The hydrophobicity of essential oils might enable them to partition in the lipid component of bacterial cell membrane, rendering them permeable and leading to leakage of bacterial cell contents ${ }^{6}$.

This study showed excellent activity of makrut leaf oil and makrut oil against many respiratory bacteria at the various activity levels. The results of disc diffusion were not highly correlated with MIC and MBC. Disc diffusion is a screening method usually used as a preliminary check for antibacterial 
activity prior to the more detailed study in liquid medium to determine MIC and MBC. There are many factors that may affect the results of disc-diffusion test, e.g., volume of essential oil placed on paper discs, thickness of agar, diffusion ability of oil in agar, and variation of essential oil concentration. Therefore, disc-diffusion method is not suitable for comparison the efficacy of essential oil. The broth microdilution method measures the strength of antibacterial activity and better be used for comparison.

The increasing incidence of multi-drug resistant A. baumannii and MRSA underscored the urgent need for effective alternative drug. The extraction of essential oil from plant is a crucial step for biosynthesis and may lead to the discovery of new drug for infectious diseases. This study revealed that all the multi-drug resistant bacteria were highly sensitive to makrut oil and makrut leaf oil. More than $80 \%$ of $A$. baumannii used in our study were resistant to all drugs tested in our routine clinical laboratory such as aminoglycosides, ampicillin, cephalosporins, carbapenem, fluoroquinolones; and only sensitive to colistin which is a drug with high nephro- and neurotoxic potential. All MRSA in our study were hospitalacquired and resistant to most drugs available.

The pure major lipid components of the essential oils, citronellal, $\alpha$-terpineol, terpinene-4-ol, and limonene, were chosen to test for the active components responsible for the antibacterial effect. In a previous study the pure lipid compounds in essential oils of Cinnamosma fragrans, linalool and 1,8cineole, were reported to be the active antimicrobial components ${ }^{19}$. To our knowledge, this is the first report of activity of the active components of makrut essential oils. The most interesting result was that $\alpha$-terpineol was the most active component. Although this component is present only $13.20 \%$ in makrut oil, bioengineering of its synthesis in plant would be possible to provide greater yield. Our results were in agreement with previous studies that $\alpha$-terpineol ${ }^{6,20}$ and terpinene-4-ol ${ }^{20}$ had antibacterial properties against foodborne pathogens, but limonene was not ${ }^{7}$.

The results from this study could be applied to clinical use. For example, we found group A streptococci, the most common pathogenic bacteria causing sore throat in human, was very sensitive to makrut lime essential oils. Development of these essential oils throat spray may lead to the prevention or treatment of streptococcal pharyngotonsillitis. Likewise, an essential oil throat spray may be able to prevent nosocomial acquired pneumonia from resistant bacteria in hospitalized patients with respiratory conditions.
Further studies are needed and may lead to clinical use of alternative medicine from natural sources.

In conclusion, makrut lime leaf oil and makrut lime oil had excellent antibacterial activities against various respiratory pathogens including the multiresistant bacteria. These essential oils may be important for drug development for prevention and treatment of many bacterial diseases.

Acknowledgements: This work was supported by the Co-ordinating Centre for Research and Development to Increase the Value of the Plants Indigenous to Thailand, Mahidol University and The Thailand Research Fund, the Vejdusit Foundation, and by Faculty of Medicine Siriraj Hospital (Graduate research fund).

\section{REFERENCES}

1. Khan AV, Ahmed QU, Shukla I, Khan AA (2010) Antibacterial efficacy of Bacopa monnieri leaf extracts against pathogenic bacteria. Asian Biomed 4, 651-5.

2. Imelouane B, Tahri M, Ankit M, Khdid K, Amhamdi H, Dubois J, ElBachiri A (2010) The essential oil of Eastern Moroccan Rosmarinus officinalis: chemical composition, in vitro antimicrobial and antioxydant activities. Rev Microbiol Ind San et Environn 4, 120-41.

3. Gutierrez J, Barry-Ryan C, Bourke P (2008) The antimicrobial efficacy of plant essential oil combinations and interactions with food ingredients. Int J Food Microbiol 124, 91-7.

4. Doreen SH, Rose LC, Suhaimi H, Mohamad H, Rozaini MZH, Tai M (2011) Preliminary evaluation on the antibacterial activities of Citrus hystrix oil emulsions stabilized by tween 80 and span 80 . Int J Pharm Pharm Sci 3 (Suppl 2), 209-11.

5. Prabuseenivasan S, Jayakumar $M$, Ignacimuthu $S$ (2006) In vitro antibacterial activity of some plant essential oils. BMC Compl Alternative Med 6, 39-47.

6. Burt S (2004) Essential oils: their antibacterial properties and potential applications in food-a review. Int $J$ Food Microbiol 94, 223-53.

7. Kim J, Marshall MR, Wei CI (1995) Antibacterial activity of some essential oil components against five foodborne pathogens. J Agr Food Chem 43, 2839-45.

8. Lambert RJ, Skandamis PN, Coote PJ, Nychas GJ (2001) A study of the minimum inhibitory concentration and mode of action of oregano essential oil, thymol and carvacrol. J Appl Microbiol 91, 453-62.

9. Karpouhtsis I, Pardali E, Feggou E, Kokkini S, Scouras ZG, Mavragani-Tsipidou P (1998) Insecticidal and genotoxic activities of oregano essential oils. $\mathrm{J} \mathrm{Agr}$ Food Chem 46, 1111-5.

10. Fontenelle RO, Morais SM, Brito EH, Brilhante RS, Cordeiro RA, Nascimento NR, Kerntopf MR, Sidrim JJ, et al (2008) Antifungal activity of essential oils of Croton species from the Brazilian Caatinga biome. J Appl Microbiol 104, 1383-90. 
11. Khan MT, Ather A, Thompson KD, Gambari R (2005) Extracts and molecules from medicinal plants against herpes simplex viruses. Antivir Res 67, 107-19.

12. Pessoa LM, Morais SM, Bevilaqua CML, Luciano JHS (2002) Antihelminthic activity of essential oil of Ocimum gratissimum Linn. and eugenol against Haemonchus contortus. Vet Parasitol 109, 59-63.

13. Nanasombat S, Lohasupthawee P (2005) Antibacterial activity of crude ethanolic extracts and essential oils of spices against salmonellae and other enterobacteria. KMITL Sci Tech J 5, 527-38.

14. Chanthaphon S, Chanthachum S, Hongpattarakere T (2008) Antimicrobial activities of essential oils and crude extracts from tropical Citrus spp. against foodrelated microorganisms. Songklanakarin J Sci Tech 30 (Suppl 1), 125-31.

15. Clinical and Laboratory Standards Institute (2010) Performance Standards for Antimicrobial Susceptibility Testing; Twentieth Informational Supplement. CLSI document M100-S20. CLSI, Wayne, PA.

16. Jorgensen JH, Turnidge JD (2007) Antibacterial susceptibility tests: dilution and disk diffusion methods. In: Murray PR, Baron EJ, Jorgensen JH, Landry ML, Pfaller MA (eds) Manual of Clinical Microbiology, 9th edn, ASM Press, Washington DC, pp 1152-72.

17. Sabulal B, Dan M, Pradeep NS, Valsamma RK, George V (2006) Composition and antimicrobial activity of essential oil from Amomum cannicarpum. Acta Pharm 56, 473-80.

18. Chaisawadi S, Thongbute D, Methawiriyaslip W, Pitakworarat N, Chaisawadi A, Jaturonrasamee K, Khemkhaw J, Tanuthumchareon W (2005) Preliminary study of antimicrobial activities on medicinal herbs of Thai food ingredients. Acta Hort 675, 111-4.

19. Randrianarivelo R, Sarter S, Odoux E, Brat P, Lebrun M, Romestand B, Menut C, Andrianoelisoa HS, et al (2009) Composition and antibacterial activity of essential oils of Cinnamosma fragrans. Food Chem 114, 680-4.

20. Carson CF, Riley TV (1995) Antibacterial activity of the major components of the essential oils of Melaleuca alternifolia. J Appl Bacteriol 78, 264-9. 